\title{
Impact of Exports on Economic Aggregates of Pakistan
}

\author{
Hasnain Naqvi $^{1 *}$ | Slobodan Adžićc ${ }^{2}$ Nebojša Zakićc $\quad$ Milijanka Ratković ${ }^{4}$ | \\ Israr Ahmad ${ }^{5}$ \\ 1 University of Hafr Al-Batin, Hafr-Al Batin, Saudi Arabia \\ 2 Arab Open University, Al-Ardia, Kuwait \\ University Union - Nikola Tesla, Faculty of management FAM, Sremski Karlovci, Serbia \\ 3 University Union - Nikola Tesla, FMN FPB, Belgrade, Serbia \\ ${ }^{4}$ University Union - Nikola Tesla, Faculty for Education of the Executives, Belgrade, Serbia \\ 5 Islamic International University, Islamabad, Pakistan
}

\begin{abstract}
The study employs CGE model, on the data provided in SAM 2007-08 for Pakistan designed by Dorosh et al. (2012), to investigate the impact of Pakistan's exports on the major aggregates of the economy. To this end, three experiments have been conducted, exports are increased by $5 \%$ in the first simulation (SIM-I), in the second simulation (SIM-II) by $10 \%$ and in the third simulation (SIMIII) by $15 \%$. The findings of the study reveal that increase in exports has favourable impact on the performance of macroeconomic variables of the economy i.e. GDP, public and private consumption, savings and investment. Domestic output level of most of the commodities has risen except mine, food manufacturing and other manufacturing. Incomes and expenditures of all the households have risen that results in rise of utility level of all the households. Moreover, all the households have also recorded an increase in the values of compensating variation which implies higher level of welfare for households. However, the value of compensating variation for non-agriculture households has risen more than that of agriculture households indicating pro-urban effect. Equality among the households has improved as the inequality indices have registered declining trend. The study suggests that export promotion measures should be incorporated in poverty alleviation, income equality and economic growth strategies.
\end{abstract}

Key words: economics, export, aggregates, CGE model. economic growth, sustainable development, Pakistan, poverty allevation

JEL Classification: B22, D58, 04, Q01, I30, I32

\section{INTRODUCTION}

Trade openness plays an important role in the economic growth of a country and helps a country to achieve higher economic growth, (Anderson and Babula, 2008), through efficient utilization of resources and transmitting economic growth from one region of the world to another. In international trade much importance is assigned to exports because exports have a profound impact on the output of a country. The importance of exports goes back to the mercantilist time. In view of mercantilists international trade is a "single-pie" and they stressed on 'more exports and less imports'. Exports are a means of valuable foreign exchange earnings which enables us to import our indispensable inputs (technology and machinery). Exports lead to employment generation, optimal utilization of resources and economic development of a country. That is why exports are considered to be an engine of economic growth. Domestic monopolies are vanished and the availability of goods is made at lower prices on one hand and

\footnotetext{
*E-mail: naqqvi23@hotmail.com
} 
incomes of the people are raised through employment generation on the other hand. These lower prices and higher incomes raise the consumption level (welfare) of people. Exports have impacted the GDP of Pakistan positively and there is a strong long-term relationship between Exports and GDP of Pakistan, (Shirazi and Manap, 2004).

The literature on the history of export performance of Pakistan shows bleak picture of the export performance of Pakistan. During 1950s and 1960s, export performance of Pakistan remained poor either because it did not receive serious attention or due to limited capacity. In general Pakistan exports showed an increasing trend both in terms of value and quantity. The rate of growth of exports remained very slow till 1972 but after that it accelerated. On the other hand, imports have increased more than exports due to which Pakistan has always confronted the problem in deficit in balance of trade (BOT) with exceptions of a few years (1950-51, 195455 and 1972-73).

The growth rate of the world output and trade witnessed deceleration in 2011 due to detrimental impact cast by the deteriorating global environment. Growth rate of the world output declined from 5.3\% in 2010 to $3.9 \%$ in 2011. In the same manner growth rate of the world trade decelerated from $13 \%$ in 2010 to $5.8 \%$ in 2011. But quite opposite to it, growth rate of Pakistan's exports accelerated from $9.06 \%$ in $2009-10$ to $28.61 \%$ in $2010-11$ and Pakistan's imports grew at the rate of -0.32 in 2009-10 to 16.43 in 2010-11. This indicates inflating volume of Pakistan external trade. Pakistan's exports are characterized by high concentration in commodity and export markets. However, shift in the nature of Pakistan's exports has been seen from primary products to manufactured products. The share of primary products in Pakistan's total exports was 33\% in 1971 which has declined to 18\% in 2011. Similarly, the share of semimanufactured goods in Pakistan's total export was 24\% in 1971 which has now declined to 12\% of total exports in 2011. On the other hand the share of manufactured goods has increased from 44\% in 1971 to 70\% in 2011 (Pakistan's Economic Survey, 2011-12).

A large number of facilities/incentives have been given to the exporters to inflate the volume of exports from Pakistan. These incentives are targeted to make exports zero-rated (exporters pay no tax on sales abroad). These facilities include export financing (in domestic and foreign currency), Export Credit Guarantee, concessionary rate of income tax (under the income Tax Ordinance 1979), Common Bonded Warehouse Scheme, Export Marketing and Product Upgradation Fund, Duty Drawback Scheme, and Export House Scheme (Haque and Kemal, 2007).

This shows that there have been no systematic trend in Pakistan's exports growth over the years that calls for its analysis as it can impact different economic aggregates in a significant way. This study aims to unfold the nexus between export and various economic aggregates in Pakistan.

\section{REVIEW OF LITERATURE}

Economists have employed CGE models for the analysis of economic policies and for the appraisal of costs and benefits accrued to nations through economic integration and trade liberalization, for example, Oslington (2005), Akerman (2005), Bouet et al. (2004) and Kurzweil (2002).

To simulate the fiscal policy, Bhattarai and Trzeciakiewicz (2016) developed a Computable General Equilibrium Model to analyze fiscal policy in United Kingdom. They found that investment and public consumption causes high GDP multiplier in short run. In long run, whereas, private investment and capital income tax have high impact on GDP. Moreover, this study also explored effectiveness of public outlays and consumption taxes.

Naqvi, et al. (2011) developed CGE model of Pakistab to analyze the impact of Agricultural Income Tax on Household Welfare and Inequality. The model analysed the economic implications of Agricultural Income Tax and reduction in sales tax for production activities to adjust the budget surplus. The objective of this experiment was to determined the possibility of 
implementation of agricultural income tax in case of Pakistan and to analyse its benefits at macro and household level. Two variables were considered in this experiment i.e., imposition of agricultural income tax, and decrease in sales tax rates. The article concluded that the imposition of agricultural income tax is beneficial in terms of household and economy-wide welfare indicators.

Bouet et al. (2010) appraised the gains and losses accrued to members and non-members of South Asia from South Asian Free Trade Agreement (SAFTA) by using CGE model. The study assessed the costs and benefits of both the cases: including the sensitive products envisaged in SAFTA and excluding them from the process of trade liberalization. Full trade liberalization (including sensitive products) had been considered to cause trade diverting effects in terms of income that was reduced due to tariff-cut. Liberalization of sensitive products was thought to be non-beneficial for LDCs of the region. The pattern of distribution of gains among the factors of production promised higher incomes for unskilled labourers, hence, pro-poor. However, the consequences of SAFTA were deemed to cause low tariff income for almost all of its members.

Ahmed and O'Donoghue (2009) analyzed the impact of variations in external balance of Pakistan developing country on the various economic entities of the economy by employing CGE model. The study integrated the economy into 33 sectors and gauged the impacts of changes in import prices and external savings on these aggregates. Simulation results of the study ascertained that increase (50\%) in foreign savings led to expansion of imports and contraction of exports. The sectors expected to face reduction in their exports were cement, leather, textile and livestock. Under these conditions the factors expected to receive increased incomes were non-agriculture unskilled wage labour and agriculture wage labour. A rise in import prices especially petroleum and industrial raw material led to decline in exports. The state of poverty and income inequality was aggravated.

Gilbert (2008) investigated the impact of integration of the South Asian economies under SAFTA on the welfare, poverty and income distribution of the concerned countries through CGE model. The main contribution of this study in the existing literature was that it took into account the whole South Asian region, not a single country for CGE approach. The findings of the study revealed that almost all of the countries except Bangladesh would gain from trade liberalization, though the gains would be modest because these countries had similar export structure. In case of Bangladesh, unilateral reforms had been proposed to be the best option. The trade reforms stipulated to be brought about under the auspices of SAFTA had been perceived to cast positive impact on overall welfare. Thus, regional integration was deemed to be pro-poor especially in Bangladesh and India. However, income inequality was liable to rise.

Panda and Kumar (2008) explored the relationships among trade liberalization, economic growth, food security and poverty through CGE model constructed for India. The study used the data provided in the SAM for India for the year 2003-04. The simulation results of the study depicted that trade liberalization had a negligible impact on the growth of GDP. It was the only agriculture sector that benefited from both unilateral and multilateral trade liberalization in GDP while non-agriculture GDP remained invariant in face of unilateral liberalization and declined under multilateral liberalization. Both wages and consumer prices rose but wages rose more than prices; hence, real incomes of all households soared. Due to rise in real income, income poverty plummeted. Consequently, lower income groups of both rural and urban sections witnessed a decline in food intake in terms of calories while others increased the intake of nutrients.

Siddiqui (2007) investigated and compared the effects of liberalization of agriculture trade in the domestic and the world economy on the economic growth of Pakistan by employing both static as well as dynamic CGE frameworks. The study used the data provided in Pakistan Social Accounting Matrix for the year 2002 (SAM 2002). The simulation results of the study depicted that liberalization of agriculture trade whether at domestic level or international level had favourable impact on the economic growth of the country. However, the effects of liberalization 
of agriculture trade at international level were found to be stronger than those of liberalization at domestic level. Complete liberalization of agriculture trade was expected to increase the incomes of both rural and urban households. However, long run consumption of rural households increased more than that of urban households. The distribution of income was, in the short run, improved while it was worsened in the long run.

Cockburn et al. (2006) investigated and compared the effects of trade liberalization on different economic aggregates of seven African and Asian countries by using CGE model. Roles of relative factor endowment, initial tariff structure, trade pattern, production pattern and income and consumption patterns were given much consideration in explaining the results. The findings of the study demonstrated that trade liberalization had varying effects on different commodity sectors and household groups. Manufacturing sector had gained while agriculture sector had lost under trade liberalization process. The urban households benefited while rural households lost in terms of welfare. Nonetheless, overall trade liberalization raised the level of welfare and reduced poverty. Wages of households increased more than the increase in domestic price of consumer goods. The pro-urban effect of trade liberalization was considered to be due to substantial fall in the returns to land.

Adam and O'Connell (2000) employed CGE model to investigate and compare the gains accrued from aid and trade preference to a recipient developing African country. The findings of the study substantiated that the gains from trade preference were dominant over the gains from aid. The study advocated for transfers (whether in the form of aid or trade) that promote capital accumulation in the receiving country. Through capital accumulation, a developing country was thought to shift from raw exports to manufactured exports. This shift, in turn, was deemed to enhance welfare effects of donor assistance. Transfer of resources via aid impacted the manufactured exports and total domestic output adversely. Contrarily, trade preferences increased domestic output and consumption. Fiscal distortions attached more importance to aid than trade because export subsidy given to promote exports would result in increased fiscal burden.

\section{METHODOLOGY}

The study has employed Computable General Equilibrium (CGE) model designed on the pattern of Lofgren et al. (2002), on the data provided in SAM 2007-08 for Pakistan designed by Dorosh et al. (2012), to investigate the impact of Pakistan's exports on its economic aggregates. The framework of mathematical equations is based on the neo-classical assumptions of optimizing behaviour of economic agents: maximization of utility and output, and minimization of costs 1 . Trade elasticities for different commodities in Pakistan have been borrowed from Ahmed et al. (2008). Three experiments have been conducted to gauge the impact of increase in Pakistan's exports on various economic aggregates of Pakistan. In the first simulation (SIM-I) Pakistan's exports have been increased by $5 \%$, in the second simulation (SIM-II) by $10 \%$ and in the third simulation (SIM-III) by 15\%.

\section{INTERPRETATION OF RESULTS}

\section{Macro level}

The GDP (at fixed cost) of Pakistan has registered growth of $1.474 \%, 2.911 \%$ and $4.314 \%$ in SIM-I, SIM-II and SIM-III respectively (table 1). This rise in GDP can be attributed to increase in investment, higher level of activities, increase in household incomes and hence higher savings. Investment has grown by $0.942 \%, 2.011 \%$ and $3.193 \%$ in the respective three experiments. This increase in investment is in line with theory as rise in institutional incomes and consequent rise

${ }^{1}$ Mathematical equations and economic aggregation can be provided on demand. 
in their savings have resulted in higher investment. Government consumption has inflated by $0.702 \%, 1.418 \%$ and $2.141 \%$ while private consumption has risen by $0.936 \%, 1.859 \%$ and $2.769 \%$ due to rise in the incomes of institutions coupled with fall in the prices of various consumer goods and fall in the price of imports in terms of domestic currency due to appreciation of domestic currency.

Table 1. National Income Accounts (\% Variation)

\begin{tabular}{|c|c|c|c|c|}
\hline & Base & $\begin{array}{c}\text { Simulation-I } \\
(5 \%)\end{array}$ & $\begin{array}{c}\text { Simulation-II } \\
(10 \%)\end{array}$ & $\begin{array}{c}\text { Simulation-III } \\
(15 \%)\end{array}$ \\
\hline GDP at Factor Prices & 3377101.000 & 1.474 & 2.911 & 4.314 \\
\hline Government Consumption & 408940.000 & 0.704 & 1.418 & 2.141 \\
\hline Investment & 534109.000 & 0.942 & 2.011 & 3.193 \\
\hline Exports & 677841.000 & 3.716 & 7.491 & 11.325 \\
\hline Imports & 1030150.000 & 1.181 & 2.517 & 3.993 \\
\hline Net Indirect Taxes & 251634.000 & -0.163 & -0.177 & -0.059 \\
\hline Private Consumption & 3037997.000 & 0.936 & 1.859 & 2.769 \\
\hline
\end{tabular}

Source: research by authors

Both exports and imports have grown but the growth rate of exports is higher than that of imports (table 2 and 3). Exports have grown by 3.716\%, 7.491\% and $11.325 \%$. This surge in exports is in conformity with economic literature as it is mainly due to rise in activity level, consequent increase in output and rise in GDP. Moreover, increase in imported inputs has led to increase in domestic output which in turn has increased the quantity of commodities to be exported. Imports have registered growth rate of $1.181 \%, 2.517 \%$ and $3.993 \%$. This positive growth of imports is mainly the result of fall in the price of imports due to appreciation of domestic currency and increase in foreign exchange reserves due to more exports.

Table 2. Quantity of Exports for Commodities (\% Variation)

\begin{tabular}{|l|r|r|r|r|}
\hline \multicolumn{1}{|c|}{ Commodities } & \multicolumn{1}{c|}{ Base } & \multicolumn{1}{c|}{$\begin{array}{c}\text { Simulation-I } \\
\text { (5\%) }\end{array}$} & $\begin{array}{c}\text { Simulation-II } \\
\text { (10\%) }\end{array}$ & \multicolumn{1}{c|}{$\begin{array}{c}\text { Simulation-III } \\
\text { (15\%) }\end{array}$} \\
\hline Agriculture & 26415 & 2.924 & 6.085 & 9.478 \\
\hline Mine & 5292 & 6.755 & 13.305 & 19.635 \\
\hline Food Manufacturing & 112975 & 1.890 & 3.868 & 5.928 \\
\hline Cotton Lint/Yarn & 60824 & 1.595 & 3.232 & 4.908 \\
\hline Textiles & 216278 & 1.734 & 3.452 & 5.157 \\
\hline Leather & 15385 & 2.903 & 5.790 & 19.667 \\
\hline Other Manufacturing & 122350 & 6.667 & 13.247 & 1.956 \\
\hline Services & 118322 & 0.689 & 1.339 & \\
\hline
\end{tabular}

Source: research by authors

Table 3. Quantity of Imports for Commodities (\% Variation)

\begin{tabular}{|l|r|r|r|r|}
\hline \multicolumn{1}{|c|}{ Commodities } & \multicolumn{1}{c|}{ Base } & \multicolumn{1}{c|}{$\begin{array}{c}\text { Simulation-I } \\
\mathbf{( 5 \% )}\end{array}$} & $\begin{array}{c}\text { Simulation-II } \\
\mathbf{( 1 0 \% )}\end{array}$ & $\begin{array}{c}\text { Simulation-III } \\
\mathbf{( 1 5 \% )}\end{array}$ \\
\hline Agriculture & 36087 & 17.960 & 37.678 & 59.154 \\
\hline Mine & 95779 & 0.720 & 1.487 & 2.296 \\
\hline Food Manufacturing & 57923 & 14.577 & 30.111 & 46.564 \\
\hline Cotton Lint/Yarn & 7297 & 14.472 & 29.952 & 46.421 \\
\hline Textiles & 18918 & 15.603 & 32.514 & 50.730 \\
\hline Leather & 1178 & 14.615 & 30.337 & 47.159 \\
\hline Other Manufacturing & 807118 & 3.609 & 7.198 & 10.766 \\
\hline Services & 53953 & 13.118 & 27.215 & 42.307 \\
\hline
\end{tabular}

Source: research by authors 


\section{Domestic output}

Output of most of the commodities has shown rising trend except mine (C-MINE), food manufacturing (C-FMAN) and other manufacturing (C-MANF) as shown in table 4.

Table 4. Level of Activities (\% Variation)

\begin{tabular}{|l|r|r|r|r|}
\hline \multicolumn{1}{|c|}{ Activities } & Base & \multicolumn{1}{c|}{$\begin{array}{c}\text { Simulation-I } \\
\text { (5\%) }\end{array}$} & $\begin{array}{c}\text { Simulation-II } \\
\text { (10\%) }\end{array}$ & \multicolumn{1}{c|}{$\begin{array}{c}\text { Simulation-III } \\
\text { (15\%) }\end{array}$} \\
\hline Agriculture & 1364731 & 0.000 & 0.000 & 0.000 \\
\hline Mine & 28424 & -1.665 & -3.156 & -4.496 \\
\hline Food Manufacturing & 673967 & -0.174 & -0.342 & -0.503 \\
\hline Cotton Lint/Yarn & 224415 & 0.289 & 0.561 & 0.820 \\
\hline Textiles & 545403 & 0.530 & 1.029 & 1.500 \\
\hline Leather & 35937 & 1.220 & 2.415 & 3.588 \\
\hline Other Manufacturing & 646118 & -0.724 & -1.342 & -1.866 \\
\hline Energy & 189246 & 0.060 & 0.117 & 0.170 \\
\hline Services & 3067054 & 0.059 & 0.106 & 0.142 \\
\hline
\end{tabular}

Source: research by authors

The highest rise in the output of leather and textile is witnessed. The output of leather (CLEAT) has increased by $1.220 \%, 2.415 \%$ and $3.58 \%$ respectively in the SIM-I, SIM-II and SIM-III. The output of those commodities has increased whose producer price and domestic price have risen and the commodities whose producer price has fallen their output has shrunk (table 5). However, the fall in the output of mine (C-MINE) is at the highest rate, it has observed the fall of $1.665 \%, 3.256 \%$ and $4.496 \%$ in the respective three experiments. On the other hand the quantity of domestic output sold domestically has fallen (table 6). Supply of composite commodities in domestic market has increased (table 7).

Table 5. Producer price for Commodities (\% Variation)

\begin{tabular}{|l|r|r|r|r|}
\hline \multicolumn{1}{|c|}{ Commodities } & Base & \multicolumn{1}{c|}{$\begin{array}{c}\text { Simulation-I } \\
\text { (5\%) }\end{array}$} & $\begin{array}{c}\text { Simulation-II } \\
\mathbf{( 1 0 \% )}\end{array}$ & \multicolumn{1}{c|}{$\begin{array}{c}\text { Simulation-III } \\
\mathbf{( 1 5 \% )}\end{array}$} \\
\hline Agriculture & 1.000 & 0.393 & 0.744 & -4.056 \\
\hline Mine & 1.000 & -1.612 & -2.970 & 1.235 \\
\hline Food Manufacturing & 1.000 & 0.432 & 0.842 & 2.010 \\
\hline Cotton Lint/Yarn & 1.000 & 0.684 & 1.353 & 2.158 \\
\hline Textiles & 1.000 & 0.719 & 1.438 & 1.734 \\
\hline Leather & 1.000 & 0.565 & 1.143 & -3.260 \\
\hline Other Manufacturing & 1.000 & -1.272 & -2.351 & 1.799 \\
\hline Energy & 1.000 & 0.552 & 1.153 & 2.446 \\
\hline Services & 1.000 & 0.802 & 1.619 & \\
\hline
\end{tabular}

Source: research by authors

Table 6. Quantity Sold Domestically of Domestic Output (\% Variation)

\begin{tabular}{|l|r|r|r|r|}
\hline \multicolumn{1}{|c|}{ Commodities } & Base & \multicolumn{1}{c|}{$\begin{array}{c}\text { Simulation-I } \\
\mathbf{( 5 \% )}\end{array}$} & $\begin{array}{c}\text { Simulation-II } \\
\mathbf{( 1 0 \% )}\end{array}$ & $\begin{array}{c}\text { Simulation-III } \\
\mathbf{( 1 5 \% )}\end{array}$ \\
\hline Agriculture & 1338316 & -0.058 & -0.121 & -0.189 \\
\hline Mine & 23132 & -3.624 & -7.051 & -10.296 \\
\hline Food Manufacturing & 560992 & -0.591 & -1.197 & -1.815 \\
\hline Cotton Lint/Yarn & 163591 & -0.198 & -0.438 & -0.714 \\
\hline Textiles & 329125 & -0.263 & -0.574 & -0.927 \\
\hline Leather & 20552 & -0.045 & -0.137 & -0.270 \\
\hline Other Manufacturing & 523768 & -2.477 & -4.852 & -7.134 \\
\hline
\end{tabular}




\begin{tabular}{|l|c|c|c|c|}
\hline \multicolumn{1}{|c|}{ Commodities } & Base & $\begin{array}{c}\text { Simulation-I } \\
\text { (5\%) }\end{array}$ & $\begin{array}{c}\text { Simulation-II } \\
\mathbf{( 1 0 \% )}\end{array}$ & $\begin{array}{c}\text { Simulation-III } \\
\text { (15\%) }\end{array}$ \\
\hline Energy & 189246 & 0.060 & 0.117 & 0.170 \\
\hline Services & 2948732 & 0.034 & 0.057 & 0.069 \\
\hline
\end{tabular}

Source: research by authors

Table 7. Quantity of Composite Goods Supplied Domestically (\% Variation)

\begin{tabular}{|l|r|r|r|r|}
\hline \multicolumn{1}{|c|}{ Commodities } & Base & \multicolumn{1}{c|}{$\begin{array}{c}\text { Simulation-I } \\
\mathbf{( 5 \% )}\end{array}$} & $\begin{array}{c}\text { Simulation-II } \\
\mathbf{( 1 0 \% )}\end{array}$ & $\begin{array}{c}\text { Simulation-III } \\
\mathbf{( 1 5 \% )}\end{array}$ \\
\hline Agriculture & 1374403 & 0.406 & 0.832 & -0.197 \\
\hline Mine & 118911 & -0.130 & -0.193 & 2.473 \\
\hline Food Manufacturing & 618915 & 0.802 & 1.627 & 1.179 \\
\hline Cotton Lint/Yarn & 170888 & 0.416 & 0.808 & 1.718 \\
\hline Textiles & 348043 & 0.582 & 1.153 & 2.163 \\
\hline Leather & 21730 & 0.735 & 1.455 & 3.604 \\
\hline Other Manufacturing & 1330886 & 1.200 & 2.402 & 0.170 \\
\hline Energy & 189246 & 0.060 & 0.117 & 0.778 \\
\hline Services & 3002685 & 0.264 & 0.523 & \\
\hline
\end{tabular}

Source: research by authors

\section{Incomes of households}

Incomes of all households have shown soaring trend in all the three experiments but the rate of increase in incomes differ from household to household (table 9). The growth rate of incomes of households who are not concerned with agriculture sector is higher than the growth rate of incomes of those who are concerned with the agriculture sector (table 7). The income of urban poor households (H-URPR) has registered highest growth rate of $1.485 \%, 2.945 \%$ and $4.381 \%$ in the three experiments. The average prices (rewards) of all the factors have increased but the rate of increase in the prices of labour whether skilled or unskilled has remained higher than that of other factors (table 8). Price of unskilled labour has registered the highest rate of growth. Moreover, the output of leather and textile has witnessed substantial increase so the demand for skilled and unskilled labour has increased leading to increase in their rewards, hence, income of these households has increased. The increased outputs of domestic commodities and increased exports have indirectly increased labour demand. Resultantly, jobless workers have got employment and a source of income.

Table 8. Average Price of Factors (\% Variation)

\begin{tabular}{|l|r|r|r|r|}
\hline \multicolumn{1}{|c|}{ Factors } & Base & \multicolumn{1}{c|}{$\begin{array}{c}\text { Simulation-I } \\
\text { (5\%) }\end{array}$} & $\begin{array}{c}\text { Simulation-II } \\
\text { (10\%) }\end{array}$ & $\begin{array}{c}\text { Simulation-III } \\
\text { (15\%) }\end{array}$ \\
\hline Own Large Farm & 1.059 & 0.659 & 1.230 & 1.725 \\
\hline Own Medium Farm & 1.058 & 0.659 & 1.230 & 1.725 \\
\hline Own Small Farm & 1.056 & 0.659 & 1.230 & 1.725 \\
\hline Agriculture Wage & 1.081 & 0.659 & 1.230 & 5.725 \\
\hline Non-Agriculture Unskilled & 1.058 & 1.878 & 3.740 & 5.316 \\
\hline Skilled & 1.037 & 1.803 & 3.574 & 1.725 \\
\hline Large Farm & 1.054 & 0.659 & 1.230 & 1.725 \\
\hline Irrigated Medium Farm & 1.063 & 0.659 & 1.230 & 1.725 \\
\hline Irrigated Small Farm & 1.059 & 0.659 & 1.230 & 1.725 \\
\hline Non-Irrigated Small Farm & 0.979 & 0.659 & 1.230 & \\
\hline Capital & 1.067 & & & \\
\hline
\end{tabular}

Source: research by authors 
Table 9. Income of Households (\% Variation)

\begin{tabular}{|c|c|c|c|c|}
\hline Households & Base & $\begin{array}{c}\text { Simulation-I } \\
(5 \%)\end{array}$ & $\begin{array}{c}\text { Simulation-II } \\
(10 \%)\end{array}$ & $\begin{array}{c}\text { Simulation-III } \\
(15 \%)\end{array}$ \\
\hline Large Farm & 93954 & 0.800 & 1.568 & 2.306 \\
\hline Medium Farm & 226190 & 0.818 & 1.602 & 2.357 \\
\hline Small Farm & 501515 & 0.937 & 1.847 & 2.735 \\
\hline Landless Farmers & 104611 & 0.905 & 1.779 & 2.628 \\
\hline Rural Agriculture Landless & 98471 & 0.948 & 1.867 & 2.760 \\
\hline Rural Non-Farm Non-Poor & 400770 & 1.303 & 2.589 & 3.861 \\
\hline Rural Non-Farm Poor & 134399 & 1.242 & 2.471 & 3.688 \\
\hline Urban Non-Poor & 1744122 & 0.775 & 1.549 & 2.321 \\
\hline Urban Poor & 181413 & 1.485 & 2.945 & 4.381 \\
\hline
\end{tabular}

Source: research by authors

\section{Welfare of households}

Table 13 depicts that overall welfare of households has increased. Incomes of households have risen as a result of rise in factor rewards and higher level of activities. Higher incomes have lifted constraints to consume more (table 10) which in turn has guaranteed higher level of utility (table 12). Moreover, the welfare effect can be assessed by comparing prices of the factors owned by households and consumer prices of commodities (CPI). Table 8 represents average prices of factors while consumer price indices have been portrayed in table 11. By comparing the results of these tables it can be concluded that average factor prices have risen at higher rate than consumer prices of commodities. Consequently real incomes of households have risen.

The results about compensating variation (CV) of households reveal that the households would be better-off in the consequence of increased Pakistan's exports. All the households have positive CV. However, the highest CV is recorded by urban non-poor, non-farm non-poor, small farm and urban poor households (H-URNP, H-NFNP, H-SF and H-URPR) respectively. The highest value of $\mathrm{CV}$ for urban non-poor and non-farm non-poor (H-URNP and H-NFNP) is due to negative change in Consumer Price Indexes (CPIs) for these households and substantial increase in average price of factors - unskilled and skilled Labour (LA-SKU and LA-SK). The households who have witnessed negative change in their respective CPIs are Large farm, Medium farm, Nonfarm non-poor, Urban non-poor households (H-LF, H-MF, H-NFNP and H-URNP). The low value of CV for Large Farm households (H-LF) is due to lower rewards of factors owned by H-LF, though it has witnessed negative change in its respective CPI. Anyhow, the lowest values of CV are recorded by Agriculture wage, non-farm and Large farm households (H-AGW, H-OF and HLF) respectively. It is evident that the households related to agriculture have received fewer gains than households related to non-agriculture.

Nevertheless, the incomes and expenditures of all the households have soared. Consequently, an increase in utility is witnessed by all the households (table 12). However, the highest utility is recorded by Non-farm non-poor, Non-farm Poor and Urban poor households (H-NFNP, H-NFP and H-URPR). Conversely, the lowest gains in terms of utility are stipulated for Non-Farm and Agriculture wage households ( $\mathrm{H}-\mathrm{OF}$ and H-AGW). Such pattern of distribution of utility also confirms that more gains are promised for households engaged in non-agriculture (urban households). However, overall, economy-wide CV has risen (table 14). 
Table 10. Consumption Expenditures of Households (\% Variation)

\begin{tabular}{|l|r|r|r|r|}
\hline \multicolumn{1}{|c|}{ Households } & Base & $\begin{array}{c}\text { Simulation-I } \\
\text { (5\%) }\end{array}$ & $\begin{array}{c}\text { Simulation-II } \\
\text { (10\%) }\end{array}$ & $\begin{array}{c}\text { Simulation-III } \\
\text { (15\%) }\end{array}$ \\
\hline Large Farm & 84554 & 0.800 & 1.568 & 2.306 \\
\hline Medium Farm & 214882 & 0.818 & 1.602 & 2.357 \\
\hline Small Farm & 476443 & 0.937 & 1.847 & 2.735 \\
\hline Landless Farmers & 99374 & 0.905 & 1.779 & 2.628 \\
\hline Rural Agriculture Landless & 93542 & 0.948 & 1.867 & 3.760 \\
\hline Rural Non-Farm Non-Poor & 360694 & 1.303 & 2.589 & 3.688 \\
\hline Rural Non-Farm Poor & 127680 & 1.242 & 2.471 & 2.321 \\
\hline Urban Non-Poor & 1408485 & 0.775 & 1.549 & 4.381 \\
\hline Urban Poor & 172343 & 1.485 & 2.945 & \\
\hline
\end{tabular}

Source: research by authors

Table 11. Household Consumer Price Index (\% Variation)

\begin{tabular}{|l|r|r|r|r|}
\hline \multicolumn{1}{|c|}{ Households } & Base & $\begin{array}{c}\text { Simulation-I } \\
\text { (5\%) }\end{array}$ & $\begin{array}{c}\text { Simulation-II } \\
\mathbf{( 1 0 \% )}\end{array}$ & $\begin{array}{c}\text { Simulation-III } \\
\text { (15\%) }\end{array}$ \\
\hline Large Farm & 1.023 & -0.126 & -0.244 & -0.355 \\
\hline Medium Farm & 1.023 & -0.130 & -0.252 & -0.367 \\
\hline Small Farm & 1.020 & 0.082 & 0.156 & 0.222 \\
\hline Landless Farmers & 1.021 & 0.140 & 0.268 & 0.385 \\
\hline Rural Agriculture Landless & 1.020 & 0.204 & 0.392 & 0.563 \\
\hline Rural Non-Farm Non-Poor & 1.022 & -0.007 & -0.015 & -0.023 \\
\hline Rural Non-Farm Poor & 1.023 & 0.143 & 0.272 & 0.390 \\
\hline Urban Non-Poor & 1.021 & -0.052 & -0.098 & -0.139 \\
\hline Urban Poor & 1.022 & 0.136 & 0.261 & 0.377 \\
\hline
\end{tabular}

Source: research by authors

Table 12. Utility of Households (\% Variation)

\begin{tabular}{|l|r|r|r|r|}
\hline \multicolumn{1}{|c|}{ Households } & Base & $\begin{array}{c}\text { Simulation-I } \\
\text { (5\%) }\end{array}$ & $\begin{array}{c}\text { Simulation-II } \\
\mathbf{( 1 0 \% )}\end{array}$ & $\begin{array}{c}\text { Simulation-III } \\
\text { (15\%) }\end{array}$ \\
\hline Large Farm & 82670 & 0.927 & 1.816 & 2.670 \\
\hline Medium Farm & 210039 & 0.949 & 1.859 & 2.734 \\
\hline Small Farm & 467056 & 0.854 & 1.689 & 2.507 \\
\hline Landless Farmers & 97329 & 0.763 & 1.507 & 2.234 \\
\hline Rural Agriculture Landless & 91732 & 0.742 & 1.470 & 2.184 \\
\hline Rural Non-Farm Non-Poor & 352910 & 1.310 & 2.604 & 3.885 \\
\hline Rural Non-Farm Poor & 124810 & 1.098 & 2.192 & 3.285 \\
\hline Urban Non-Poor & 1379794 & 0.827 & 1.648 & 2.463 \\
\hline Urban Poor & 168712 & 1.347 & 2.677 & 3.990 \\
\hline
\end{tabular}

Source: research by authors

Table 13. Compensating Variation of Households

\begin{tabular}{|l|r|r|r|}
\hline \multicolumn{1}{|c|}{ Households } & $\begin{array}{c}\text { Simulation-I } \\
\mathbf{( 5 \% )}\end{array}$ & $\begin{array}{c}\text { Simulation-II } \\
\mathbf{( 1 0 \% )}\end{array}$ & \multicolumn{1}{c|}{$\begin{array}{c}\text { Simulation-III } \\
\mathbf{( 1 5 \% )}\end{array}$} \\
\hline Large Farm & 783.018 & 1531.453 & 2249.628 \\
\hline Medium Farm & 2036.844 & 39833.94 & 5852.417 \\
\hline Small Farm & 4074.444 & 8060.780 & 11972.136 \\
\hline Landless Farmers & 759.681 & 1501.683 & 2228.701 \\
\hline Rural Agriculture Landless & 695.911 & 1380.172 & 2054.809 \\
\hline Rural Non-Farm Non-Poor & 4724.538 & 9392.037 & 14010.118 \\
\hline Rural Non-Farm Poor & 1403.589 & 2806.924 & 4210.789 \\
\hline
\end{tabular}




\begin{tabular}{|l|c|c|r|}
\hline \multicolumn{1}{|c|}{ Households } & $\begin{array}{c}\text { Simulation-I } \\
\mathbf{( 5 \% )}\end{array}$ & $\begin{array}{c}\text { Simulation-II } \\
\mathbf{( 1 0 \% )}\end{array}$ & $\begin{array}{c}\text { Simulation-III } \\
\text { (15\%) }\end{array}$ \\
\hline Urban Non-Poor & 11648.041 & 23194.694 & 34648.929 \\
\hline Urban Poor & 2322.181 & 4624.842 & 6901.769 \\
\hline
\end{tabular}

Source: research by authors

Table 14. Economy Wide Compensating Variation

\begin{tabular}{|c|c|c|c|}
\hline & $\begin{array}{c}\text { Simulation-I } \\
(5 \%)\end{array}$ & $\begin{array}{c}\text { Simulation-II } \\
(10 \%)\end{array}$ & $\begin{array}{c}\text { Simulation-III } \\
(15 \%)\end{array}$ \\
\hline Total Compensating Variation & 0.937 & 1.859 & 2.769 \\
\hline
\end{tabular}

Source: research by authors

\section{Inequality}

Inequality has been a question of debate. A great deal of economic literature has been devoted to answer whether inequality retards the process of economic growth or not? A number of different techniques and indicators are used by economists to measure inequality but the most popular and common in practice are Hoover index and Theil indices: Theil-L, Theil-T and Theil-S. These indicators measure intra-group and inter group inequality. However, in this study inequality among groups has been measured. The results of these indices, as depicted in table 15, show that inequality among the household groups has decreased with the increase in Pakistan's exports as these indices have shown smaller values in SIM-I than in SIM-II and so on.

Table 15. Indices of Inequality

\begin{tabular}{|c|c|c|c|c|}
\hline Indices & Base & $\begin{array}{c}\text { Simulation-I } \\
(5 \%)\end{array}$ & $\begin{array}{c}\text { Simulation-II } \\
(10 \%)\end{array}$ & $\begin{array}{c}\text { Simulation-III } \\
(15 \%)\end{array}$ \\
\hline Theil-T & 0.318 & 0.317 & 0.316 & 0.315 \\
\hline Theil-L & 0.326 & 0.325 & 0.324 & 0.323 \\
\hline Theil-S & 0.322 & 0.321 & 0.320 & 0.319 \\
\hline Hoover Index & 0.346 & 0.345 & 0.344 & 0.344 \\
\hline
\end{tabular}

Source: research by authors

\section{CONCLUSION}

The study employs CGE model, on the data provided in SAM 2007-08 for Pakistan designed by Dorosh et al. (2012). Trade elasticities for different commodities in Pakistan have been borrowed from Ahmed et al. (2008). Three experiments are performed to gauge the impact of increase in Pakistan's exports on its various economic aggregates. Pakistan's exports have been increased by $5 \%$ in the first simulation (SIM-I), in the second simulation (SIM-II) by $10 \%$ and in the third simulation (SIM-III) by 15\%. The findings of the study reveal that increase in exports has favourable impact on the performance of macroeconomic variables of Pakistan's economy i.e. GDP, public and private consumption, savings and investment. Domestic output level of most of the commodities has risen except mine, food manufacturing and other manufacturing. Incomes and expenditures of all the households have risen. Resultantly, utility level of all the households has risen. Moreover, all the households have also recorded an increase in the values of compensating variation which implies higher level of welfare for households. However, the value of compensating variation for non-agriculture households has risen more than that of agriculture households indicating pro-urban effect. Equality among the households has improved as the inequality indices have registered declining trend. All this suggests that export promotion measures should be incorporated in poverty alleviation, income equality and economic growth strategies. 


\section{REFERENCES}

Adam, Christopher S., and Stephen A. O'Connell. 2000. “Aid Versus Trade Revisited." WPS 2000-19.

Ahmed, Vaghar, and Cathal O'Donoghue. 2009. “External Shocks in a Small Open Economy: A CGE-Microsimulation Analysis." Department of Economics, National University of Ireland, Galway. Working Paper No. 0142.

Akerman, Frank. 2005. "The Shrinking Gains from Trade: A Critical Assessment of Doha Round Projections." GDAE Working Paper No. 05-01.

Anderson, Lili, and Ronald Babula. 2008. "The Link between Openness and Long-Run Economic Growth." Journal of International Commerce and Economics, United States International Trade Commission.

Bhattarai, Keshab, and Dawid Trzeciakiewicz. 2017. "Macroeconomic impacts of fiscal policy shocks in the UK: A DSGE analysis," Economic Modelling, Elsevier, vol. 61(C):, pages 321-338.

Bouët, Antoine, Jean-Christophe Bureau, Yvan Decreux, and Sébastien Jean. 2004. "Multilateral Agricultural Trade Liberalization: The Contrasting Fortunes of Developing Countries in the Doha Round." CEPII.

Bouët, Antoine, Simone Mevel, and Marcelle Thomas. 2010. "Is SAFTA Trade Creating or Trade Diverting? A Computable General Equilibrium Assessment with a Focus on Sri Lanka." IFPRI Discussion Paper No. 00950.

Cockburn, John, Bernard Decaluwé, and Véronique Robichaud. 2006. "Trade Liberalization and Poverty: lessons from Asia and Africa." Poverty and Economic Policy, Micro Impact of Macro and Adjust Policies (MIMAP) Project.

Dorosh, Paul A., Dario Debowicz, Sherman Robinson, and Syed Hamza Haider. 2012. "A 2007-08 social accounting matrix for Pakistan:," PSSP working papers 1, International Food Policy Research Institute (IFPRI).

Gilbert, John. 2008. "Trade Policy, Poverty and Income Distribution in Computable General Equilibrium Models: An Application to the South Asian Free Trade Agreement." Macao Regional Knowledge Hub, Working Papers, No. 14.

Haque, Nadeem, and M. Ali Kemal. 2007. "Impact of Export Subsidies on Pakistan's Exports." PIDE Working Papers 2007: 26.

Kurzweil, Marianne. 2002. "The Need for a Complete Labour Market in CGE Modeling." Landbauforschung Volkenrode 52(2): 102-119.

Lofgren, Hans, Rebecca Lee Harris, Sherman Robinson, Marcelle Thomas, and Moataz ElSaid. 2002. "A Standard Computable Equilibrium Model in GAMS." International Food Policy Research Institute, Washington D. C. Microcomputers in Policy Research 5.

Naqvi, Hasnain A., Muhammad Mohsin Hakeem, Rashid A. Naeem. 2011. "Impact of Agricultural Income Tax on Household Welfare and Inequality: Pakistan A Case-in-Point" International Journal of Business and Social Science 2 (6):, 103-118

Oslington, Paul. 2005. "Unemployment and Trade liberalization." World Economy 28(8): 11391155.

Panda, Manoj, and A. Ganesh-Kumar. 2008. "Trade Liberalization, Poverty and Food Security in India." Indira Gandhi Institute of Development Research, WP-2008-013.

Shirazi, Nasim Shah, and Turkhan Ali Abdul Manap. 2004. "Exports and Economic Growth Nexus: The Case of Pakistan." The PDR, 43:4 Part II (Winter 2004): 563-581.

Siddiqui, Rizwana. 2007. "Dynamic Effects of Agriculture Trade in the Context of Domestic and Global Liberalization: A CGE Analysis for Pakistan.” PIDE Working Papers, 2007:38.

\begin{tabular}{l|l}
\hline Article history: & Received: March 26, 2018 \\
\cline { 2 - 2 } & Accepted
\end{tabular}

Accepted: June 20, 2018 